\title{
Primary and Secondary Dentine Thickness at the Apical Foramen of the Mesial and Distal Root of the Lower First Permanent Molar
}

\author{
Milica Jovanović-Medojević \\ Department of Restorative Dentistry and Endodontics, School of Dentistry, University of Belgrade, Belgrade, Serbia
}

\begin{abstract}
Summary
Introduction Knowledge of the complexity of the root canal system in lower first molars and particularly the apical part of the root affects significantly the realisation and success of the endodontic procedure.

Aim The aim of this paper was to determine the thickness of the primary and secondary dentine around the main foramen of the mesial and distal root of the lower first permanent molar in teeth of various ages.

Material and Method Fifty extracted lower first molars of both male and female patients extracted for various reasons were used in the study. All teeth were allocated to three age groups: under 25 years old ( 15 teeth), between 26 and 50 (20 teeth) and over 51 years old (15 teeth). After access cavity preparation, canal orifices were enlarged and root canals were explored using hand K-files \#10. Using a diamond disc, the root tip was then cut off in the area of the apical foramen. Dentine thickness was determined using a complex configuration comprising of several devices which were interconnected by software. These included a polarised microscope (Leica DMLSP), a digital camera (Leica DC300) and a scanner.

Results The results showed that the greatest mean thickness of the primary dentine was in the mesial root of the first lower molar in the first age group $(0.177 \mathrm{~mm})$, followed by the third $(0.145 \mathrm{~mm})$ whilst the least mean thickness was observed in the second age group $(0.141 \mathrm{~mm})$. In the distal root, the mean thickness of the primary dentine was in the second $(0.175 \mathrm{~mm})$, then the first $(0.138 \mathrm{~mm})$ and finally the third group $(0.100 \mathrm{~mm})$. The mean thickness of the secondary dentine in the mesial root was observed in the second group $(1.25 \mathrm{~mm})$, followed by the third $(1.11 \mathrm{~mm})$ whilst the least mean thickness was found in the first age group $(0.95 \mathrm{~mm})$. The mean thickness of the secondary dentine in the distal root was observed in the second group $(1.26 \mathrm{~mm})$, then the third $(1.18 \mathrm{~mm})$ whilst the least mean thickness was found in the first age group $(0.99 \mathrm{~mm})$.

Conclusion The obtained results suggested that the mean thickness of the primary dentine in the mesial and distal roots was comparable. For both mesial and distal roots, the greatest mean thickness of the secondary dentine was observed in the second age group.
\end{abstract}

Keywords: lower first molar; root canal; dentine; dental anatomy; endodontic treatment

\section{INTRODUCTION}

Knowledge of the morphology of the root canal system is the main precondition for a successful endodontic treatment. Pulp-dentine complex, as all human tissues, goes through certain changes during the aging process. One of the most important changes is the reduction of volume of the pulp chamber and root canals due to the constant dentine production [1]. In older teeth, root canal is often in the form of a thin groove and sometimes may be completely obliterated. Such a continuous restriction of pulp chamber volume leads to the reduction of pulp vascularisation and often numerous changes in metabolism but also problems in pulp therapy [2]. These changes are mainly due to aging as well as many physiological and pathological factors. Physiological changes occur as adaptation to physiological stimuli over time whilst pathological changes develop when certain factors surpass adaptive physiological capacities [3].

With aging, secondary dentine becomes irregular with a tendency to obliterate dentinal tubules [4]. The biggest changes occur in intratubular dentine with subse- quent tubular sclerosis i.e. the formation of transparent dentine. The formation of non-tubular dentine starts from the root apex and expands towards the crown leading to the reduced dentine permeability [2]. This is often used to assess dentine age since there is a statistically significant correlation between the reduction of dentinal tubules and age [5].

Changes with age occur in hard dental tissues and affect the appearance and function of the pulp. Apical deposition of secondary dentine and cementum narrow the original orifice diameter which blood and lymph vessels and nerve fibres pass through. This passage may be compromised by the orifice narrowing and in extreme old age may cease completely pulp vascularisation, lymph drainage and innervation $[5,6]$.

The number of cells starts to decrease after the age of 20 and is reduced to a half in the seventies. Physiological activity of the pulp and periodontium results in modelling and re-modelling of the anatomy of the root apical third and also the apical cone which is of utmost importance for the success of endodontic treatment $[7,8]$. 
Modern trends in endodontic therapy include the biological approach towards root canal preparation with an imperative to maintain its original length and shape. The most challenging part of the root canal preparation is the apical third which may be prepared using various endodontic techniques (Step-back, Crown-down). This procedure enables preparation, irrigation and medication of the apical portion. All complications during canal preparation such as instrument or root fracture, the weakening of root canal walls etc. may be avoided if the endodontist knows the shape, curvature and volume of this segment. The basic principle for root canal preparation is to maintain the original anatomic shape with as little as possible removal of dentine especially in the apical portion. Since the first lower molar is the key to maintaining normal occlusal relationships and functions of the entire dentognatic system, its presence in the mouth is the greatest challenge for many dentists.

The aim of this paper was to determine the thickness of the primary and secondary dentine around the main foramen of the mesial and distal root of the lower first permanent molar in teeth of various ages.

\section{MATERIAL AND METHOD}

Fifty extracted lower first molars of patients of both sexes, extracted for various reasons, were used in the study. All teeth were allocated to three age groups: Group I - samples under 25 years old ( 15 teeth); Group II - samples between 26 and 50 (20 teeth); Group III - samples over 51 years old (15 teeth). All teeth were kept in $4 \%$ formalin solution after extraction. After detailed debridement of soft and hard tissue remnants from the crown and root, the samples were kept in saline until the beginning of the study. Access cavity preparation was done in all teeth using fissure diamond burs and a high-speed handpiece. Root canal orifices were enlarged using rotary instruments (Peeso \#2) and the exploration of coronal and middle thirds was conducted using hand K-files \#10. Root tips were cut off using a diamond disc (Disco Plan-TS) in the area of apical foramen. A second section was made $1 \mathrm{~mm}$ coronally in order to prepare a sample which would be possible to observe under the polarised microscope.

The study was conducted at the Dept. of petrology of the Institute for mineralogy, crystallography, petrology and geochemistry, Faculty of Mine and Geology, Belgrade. The present study analysed apical thirds of the mesial and distal root of the lower first molar in three age groups. A complex configuration of devices was used, which was interconnected by software (Figure 1). This included a polarised microscope (Leica DMLSP) with a mounted digital camera (Leica DSC 300). Real-time imaging was enabled by specific software (Leica IM 50). The equipment also included a scanner for scanning samples in the reflected light using special foils.

Microscopic analysis included several procedures:

1. Preparation of petrographic samples

2. Observation and description of samples in the reflected light of the polarised microscope

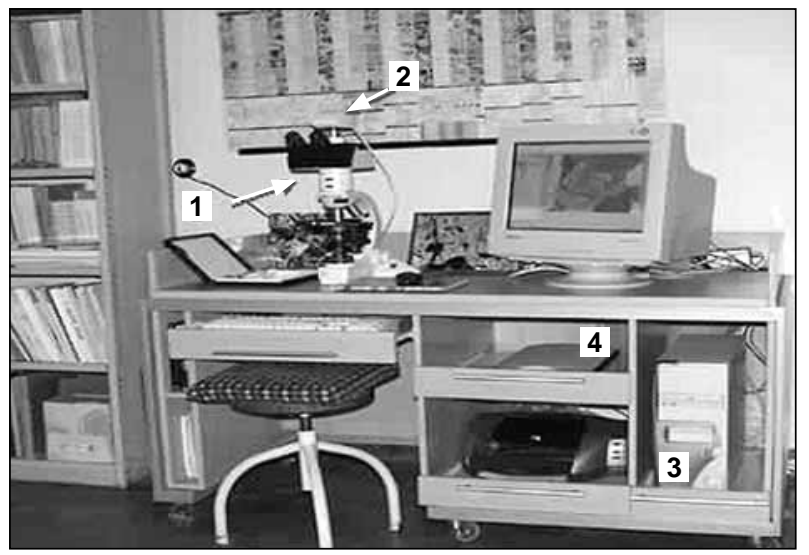

Figure 1. System configuration for the microscopic analysis of samples: microscope (1), digital camera (2), computer (3), and scanner (4). Slika 1. Sistem uređaja koji je korišćen za mikroskopsku analizu uzoraka: mikroskop (1), digitalna kamera (2), računar (3) i skener (4).

3. Taking and analysis of sample microphotographs

4. Sample scanning in the reflected light

5. Image analysis.

\section{Preparation of petrographic samples}

Petrographic sample is a thin slice of a rock sample (0.02 $\mathrm{mm}$ thick) glued between the microscopic slide and cover glass. This thin slice is transparent and this ability to pass the light enables polarised microscopic analysis. From the apical thirds of tooth roots (with necessary adjustments in the procedure) similar slices were prepared with minimal thickness of $0.025-0.030 \mathrm{~mm}$.

The preparation of these samples comprised the following procedures:

- Sectioning (apical third of the root) with diamond discs (Disco Plan-TS) from the root tip until tubular orifices

- Sample polishing

- Sample gluing to the microscopic slide using twocomponent glue Cerapox (refractive index about 1.537)

- Fine polishing of the entire sample with 600-1200 grit abrasives

- Application of the protective spray layer.

\section{Analysis under the polarised microscope}

Polarised microscope enables sample observation in the polarised light. Conventional white light is used as the light source which is linearly polarised through a polariser and reflected to the sample which is then observed. Each sample (mineral, glass, tooth root etc.) modifies this light according to their optical properties. The modified light then passes through an objective and reaches the so-called analyser. If this plate is off, the sample is observed in the parallel-nicole configuration (N//) and if the plate is on, the sample is observed in the cross-nicole configuration $(\mathrm{Nx})$. After the analyser, the light passes through an ocular and reaches the observer's eye which deciphers the light as a function of optical characteristics of the sample and determines the aim of the analysis. 
The samples of root apical thirds were observed in orthoscopic configuration with cross-nicoles because tissue morphology was most obvious in such conditions.

\section{Taking and analysis of sample microphotographs}

Microphotographs were taken in the cross-nicoles configuration using an objective with $\times 5$ magnification and an ocular with $\mathrm{x} 10$. Subsequent image editing was done in Photoshop 7 and Corel Photopaint 9.0.

Often was $\times 5$ magnification unnecessary because the sample area could not be placed in the camera field. Therefore, the disadvantage of using an objective with smaller magnification was compensated by making sets of photographs (2-6 images) which partly overlapped. These images were joined into one large representative image using Canon Photostitcher 2.2.

\section{Sample scanning}

Additional study was done by analysing scanned images of samples in reflected light. During scanning, special foils were used to mirror the effect of cross-nicoles in the polarised microscope so it was possible to distinguish various tissues, their morphology, changes, etc.

\section{Image analysis}

Images of apical foramen sections obtained under the polarised microscope were analysed in the graphic software Photoshop 7. Real dimensions were measured using a calliper (Calipretto-S 1122-1000, Renfert, Germany) and these values were transferred to Image Size during image analysis. Real dimensions of various structures in the sample were determined based on the automatic ratio in Photoshop 7. In this way were determined the foramen diameter, the thickness of the primary and secondary dentine and cementum in the mesial and distal root of lower first molars.

\section{RESULTS}

The greatest mean thickness of the primary dentine in the mesial root was observed in Group I $(0.177 \mathrm{~mm})$, followed by Group III $(0.145 \mathrm{~mm})$ whilst the least mean thickness was found in Group II (0.141 mm) (Table 1 and Figure 2).

The greatest mean thickness of the primary dentine in the distal root was found in Group II $(0.175 \mathrm{~mm})$, followed by Group I $(0.138 \mathrm{~mm})$ whilst the least mean thickness was found in Group III (0.100 mm) (Table 1).

The greatest mean thickness of the secondary dentine in the mesial root was observed in Group II (1.25 mm), then in Group III $(1.11 \mathrm{~mm})$ and the least mean thickness was found in Group I (0.95 mm) (Table 2).

The greatest mean thickness of the secondary dentine in the distal root was observed in Group II (1.26 mm), then in Group III (1.18 mm) and the least mean thickness was found in Group I (0.99 mm) (Table 3 and Figure 3).

\section{DISCUSSION}

Since the first lower molar is the key to maintaining normal occlusal relationships and functions of the entire

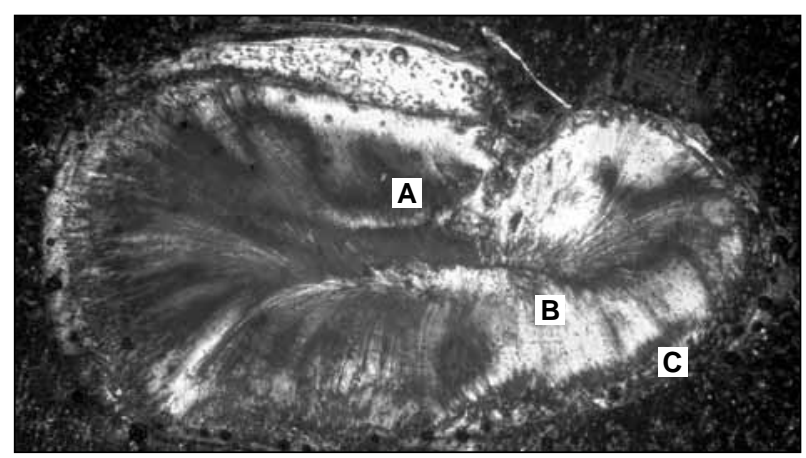

Figure 2. Apical foramen section of the mesial root of the lower first molar

Slika 2. Snimak preseka apeksnog otvora mezijalnog korena donjeg prvog molara

A - apical foramen; B - wide layer of the primary dentine;

C - cementum

A - apeksni otvor; B - širok sloj primarnog dentina; C - cement

Table 1. Primary dentine thickness in the mesial $(M)$ and distal (D) root of the lower first molar

Tabela 1. Debljina primarnog dentina na mezijalnom (M) i distalnom (D) korenu prvog donjeg molara

\begin{tabular}{|c|c|c|c|c|c|}
\hline \multirow{2}{*}{$\begin{array}{l}\text { Parameter } \\
\text { Parametar }\end{array}$} & \multirow{2}{*}{$\begin{array}{l}\text { Root } \\
\text { Koren }\end{array}$} & \multicolumn{3}{|c|}{$\begin{array}{c}\text { Sample age (years) } \\
\text { Starost uzoraka (godine) }\end{array}$} & \multirow{2}{*}{$\begin{array}{l}\text { Total } \\
\text { Ukupno }\end{array}$} \\
\hline & & $<25$ & $25-50$ & $>50$ & \\
\hline \multirow{2}{*}{$\begin{array}{l}\text { Number of samples } \\
\text { Broj uzoraka }\end{array}$} & $M$ & 15 & 20 & 15 & 50 \\
\hline & $\mathrm{D}$ & 15 & 20 & 15 & 50 \\
\hline \multirow{2}{*}{$\begin{array}{l}\text { Number of samples without cementosis } \\
\text { Broj uzoraka bez cementoze }\end{array}$} & $M$ & 13 & 12 & 8 & 33 \\
\hline & $\mathrm{D}$ & 15 & 11 & 10 & 36 \\
\hline \multirow{2}{*}{$\begin{array}{l}\text { Minimum }(\mathrm{mm}) \\
\text { Najmanja vrednost }(\mathrm{mm})\end{array}$} & $M$ & 0.015 & 0.060 & 0.041 & 0.015 \\
\hline & D & 0.010 & 0.077 & 0.027 & 0.010 \\
\hline \multirow{2}{*}{$\begin{array}{l}\text { Maximum }(\mathrm{mm}) \\
\text { Najveća vrednost }(\mathrm{mm})\end{array}$} & $M$ & 0.693 & 0.309 & 0.347 & 0.693 \\
\hline & D & 0.594 & 0.413 & 0.207 & 0.594 \\
\hline \multirow{2}{*}{$\begin{array}{l}\text { Mean value }(\mathrm{mm}) \\
\text { Prosečna vrednost }(\mathrm{mm})\end{array}$} & $M$ & 0.177 & 0.141 & 0.145 & 0.156 \\
\hline & $\mathrm{D}$ & 0.138 & 0.175 & 0.100 & 0.139 \\
\hline \multirow{2}{*}{$\begin{array}{l}\text { Standard deviation } \\
\text { Standardna devijacija }\end{array}$} & $M$ & 0.198 & 0.064 & 0.102 & 0.137 \\
\hline & D & 0.143 & 0.090 & 0.060 & 0.111 \\
\hline \multirow{2}{*}{$\begin{array}{l}\text { Coefficient of variation } \\
\text { Koeficijent varijacije }\end{array}$} & $M$ & 111.92 & 45.39 & 70.39 & 87.50 \\
\hline & $\mathrm{D}$ & 103.19 & 51.38 & 60.59 & 79.69 \\
\hline
\end{tabular}


Table 2. Secondary dentine thickness in the mesial root of the lower first molar

Tabela 2. Debljina sekundarnog dentina mezijalnog korena prvog donjeg molara

\begin{tabular}{|c|c|c|c|c|c|}
\hline \multirow{2}{*}{$\begin{array}{l}\text { Parameter } \\
\text { Parametar }\end{array}$} & \multirow{2}{*}{$\begin{array}{l}\text { Thickness } \\
\text { Debljina }\end{array}$} & \multicolumn{3}{|c|}{$\begin{array}{c}\text { Sample age (years) } \\
\text { Starost uzoraka (godine) }\end{array}$} & \multirow{2}{*}{$\begin{array}{l}\text { Total } \\
\text { Ukupno }\end{array}$} \\
\hline & & $<25$ & $25-50$ & $>50$ & \\
\hline \multirow{2}{*}{$\begin{array}{l}\text { Number of samples } \\
\text { Broj uzoraka }\end{array}$} & Max & 15 & 20 & 15 & 50 \\
\hline & Min & 15 & 20 & 15 & 50 \\
\hline \multirow{2}{*}{$\begin{array}{l}\text { Number of samples without cementosis } \\
\text { Broj uzoraka bez cementoze }\end{array}$} & Max & 14 & 16 & 10 & 40 \\
\hline & Min & 14 & 16 & 10 & 40 \\
\hline \multirow{2}{*}{$\begin{array}{l}\text { Minimum (mm) } \\
\text { Najmanja vrednost }(\mathrm{mm})\end{array}$} & Max & 0.45 & 0.47 & 0.45 & 0.45 \\
\hline & Min & 0.08 & 0 & 0.14 & 0 \\
\hline \multirow{2}{*}{$\begin{array}{l}\text { Maximum }(\mathrm{mm}) \\
\text { Najveća vrednost }(\mathrm{mm})\end{array}$} & Max & 1.68 & 3.22 & 2.47 & 3.22 \\
\hline & Min & 0.77 & 1.04 & 0.44 & 1.04 \\
\hline \multirow{2}{*}{$\begin{array}{l}\text { Mean value }(\mathrm{mm}) \\
\text { Prosečna vrednost }(\mathrm{mm})\end{array}$} & Max & 0.95 & 1.25 & 1.11 & 1.11 \\
\hline & Min & 0.27 & 0.35 & 0.26 & 0.30 \\
\hline \multirow{2}{*}{$\begin{array}{l}\text { Standard deviation } \\
\text { Standardna devijacija }\end{array}$} & Max & 0.37 & 0.76 & 0.62 & 0.61 \\
\hline & Min & 0.17 & 0.28 & 0.12 & 0.21 \\
\hline \multirow{2}{*}{$\begin{array}{l}\text { Coefficient of variation } \\
\text { Koeficijent varijacije }\end{array}$} & Max & 39.02 & 60.66 & 56.27 & 55.17 \\
\hline & Min & 64.49 & 78.10 & 45.06 & 70.19 \\
\hline
\end{tabular}

Max - greatest thickness; Min - least thickness

Max - najveća debljina; Min - najmanja debljina

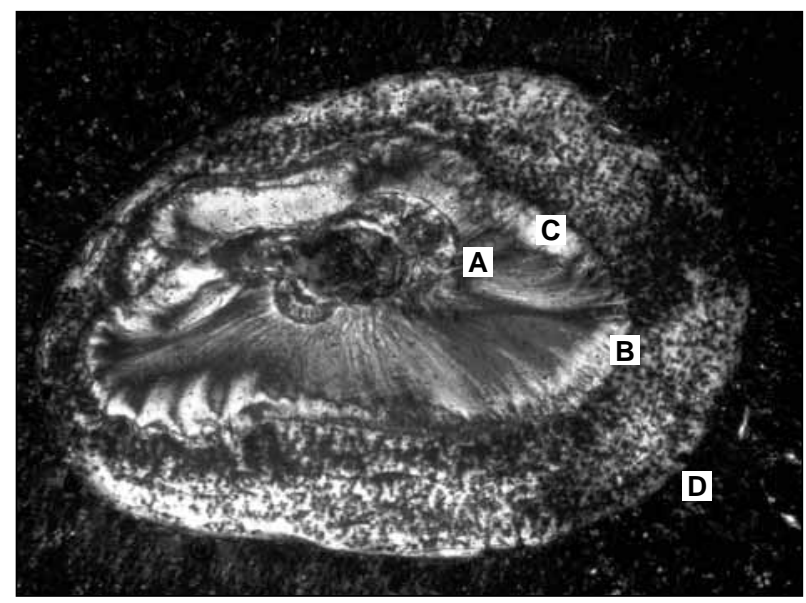

Figure 3. Apical foramen section of the distal root of the lower first molar

Slika 3. Snimak preseka apeksnog otvora distalnog korena donjeg prvog molara

A - apical foramen; B - primary dentine; C - secondary dentine;

D - cementum

A - apeksni otvor; B - primarni dentin; C - sekundarni dentin;

D - cement dentognatic system, its presence in the mouth is the greatest challenge for many dentists. Relative simplicity and uniformity of the surface of mesial and distal roots often mimics their internal complexity $[9,10]$.

Two-rooted mandibular molar most often has 3 root canals. Two are located in the mesial root and one in the distal. Many studies confirmed that the mesial root always has 2 canals (mesial-buccal and mesial-lingual) but with different Vertucci configuration. Analyses of morphological variations of these teeth showed that type III was present in $60 \%$ and type II in $40 \%$ of cases [7].

The distal root usually has one canal with type II Vertucci configuration [7]. Both the mesial and distal roots are of interest to endodontists because of the possible isthmuses due to their internal configuration. Isthmus is a narrow, ribbon-like joint between two root canals which contains pulp tissue and has different names in the literature. It is known as corridor (Green 1973), lateral branches (Pineda 1973) or transversal anastomosis (Vertucci 1984). It is important to point out that every root with two canals has the high prevalence of isthmuses [11]. Weller et al. (1995) showed that an isthmus is often found 3-5 mm from the apex. Isthmus is a great endodontic challenge

Table 3. Secondary dentine thickness in the distal root of the lower first molar

Tabela 3. Debljina sekundarnog dentina distalnog korena prvog donjeg molara

\begin{tabular}{|c|c|c|c|c|c|}
\hline \multirow{2}{*}{$\begin{array}{l}\text { Parameter } \\
\text { Parametar }\end{array}$} & \multirow{2}{*}{$\begin{array}{l}\text { Thickness } \\
\text { Debljina }\end{array}$} & \multicolumn{3}{|c|}{$\begin{array}{c}\text { Sample age (years) } \\
\text { Starost uzoraka (godine) }\end{array}$} & \multirow{2}{*}{$\begin{array}{l}\text { Total } \\
\text { Ukupno }\end{array}$} \\
\hline & & $<25$ & $25-50$ & $>50$ & \\
\hline \multirow{2}{*}{$\begin{array}{l}\text { Number of samples } \\
\text { Broj uzoraka }\end{array}$} & Max & 15 & 16 & 7 & 38 \\
\hline & Min & 15 & 16 & 7 & 38 \\
\hline \multirow{2}{*}{$\begin{array}{l}\text { Minimum (mm) } \\
\text { Najmanja vrednost }(\mathrm{mm})\end{array}$} & Max & 0.38 & 0.14 & 0.54 & 0.14 \\
\hline & Min & 0.1 & 0 & 0.14 & 0 \\
\hline \multirow{2}{*}{$\begin{array}{l}\text { Maximum }(\mathrm{mm}) \\
\text { Najveća vrednost }(\mathrm{mm})\end{array}$} & Max & 3.99 & 2.49 & 1.74 & 3.99 \\
\hline & Min & 0.94 & 1.5 & 0.96 & 1.5 \\
\hline \multirow{2}{*}{$\begin{array}{l}\text { Mean value }(\mathrm{mm}) \\
\text { Prosečna vrednost }(\mathrm{mm})\end{array}$} & Max & 0.99 & 1.26 & 1.18 & 1.14 \\
\hline & Min & 0.31 & 0.51 & 0.50 & 0.43 \\
\hline \multirow{2}{*}{$\begin{array}{l}\text { Standard deviation } \\
\text { Standardna devijacija }\end{array}$} & Max & 0.89 & 0.60 & 0.46 & 0.70 \\
\hline & Min & 0.20 & 0.38 & 0.26 & 0.31 \\
\hline \multirow{2}{*}{$\begin{array}{l}\text { Coefficient of variation } \\
\text { Koeficijent varijacije }\end{array}$} & Max & 90.39 & 47.61 & 38.64 & 62.00 \\
\hline & Min & 64.97 & 73.41 & 52.23 & 70.99 \\
\hline
\end{tabular}

Max - greatest thickness; Min - least thickness

Max - najveća debljina; Min - najmanja debljina 
since it may act as a bacterial reservoir, and its inadequate preparation or complete neglect may result in endodontic failure $[12,13]$.

Other interesting studies [14] showed that roots of teeth with masticatory centres (mesial-buccal root of the upper molar and distal root of the lower molar) have the greatest deviations of the apical foramen. These roots absorb the greatest masticatory stress and the accumulation of cementum represents the adaptive response to functional and physiological stresses [15].

The theory that the age of 50 is a crucial point in dentine productive potential was based on the results of the mean thickness of the secondary dentine in the mesial and distal root of the first lower molar [3]. The greatest values for dentine thickness were observed in the second age group and decreased in the third. It is important to point out the cause-and-effect relationship between the maximum and minimum thickness of the secondary dentine. Using linear regression equation, if one value is known, the other can be calculated easily. There is no data in the literature to compare the present results of the primary and secondary dentine thickness in the apical region of the mesial and distal root of the lower first molar. Therefore, the present results are original, rare and, of course, very important for endodontic treatment $[15,17,18,19]$.

Certain limitations of the present metric data can be explained by the sampling process i.e. unknown cause of extraction (orthodontic reasons, periapical infection). It was confirmed that the primary dentine thickness in the mesial and distal root of the lower first molar may differ with different methods of tooth extraction [20].

It is important to observe the complexity of the root canal system, particularly in complicated forms of lower first molars, and establish the correct diagnosis prior to the beginning of the endodontic treatment. In other words, the correct diagnosis with precise anatomical knowledge must be accompanied by perfect biomechanical preparation. All these factors lead to successful three-dimensional obturation of the root canal system [15].

Apical preparation in curved and narrow root canals (such as mesial-buccal and mesial-lingual canals of lower first molars) may be accompanied by various difficulties. Endodontic instruments are applied with greater pressure on the opposite wall of the root curvature which may result in even greater curvature and difficulties in irrigation, enlargement and obturation [21]. During endodontic treatment, it is essential to localise the precise point of apical constriction as well as the volumetric extension of biomechanical preparation of the apical third in order to avoid problems and vertical root fracture during instrumentation and obturation. Excessive enlargement of the apical region may weaken the dentinal wall which may fracture during gutta-percha compaction. This, of course, results in complete endodontic failure but may also require changes in the original prosthodontic treatment planning if such a tooth must be extracted [20].

Tapered root canal preparation has been an endodontic trend for the past two decades. Wide tapered preparation of the coronal part of the root canal is essential in endodontic treatment of complicated molar systems since it enables better access to the apical part, instrumentation control, better irrigation and more efficient removal of the smear layer. Rotary instruments (Gates Glidden and Peeso) are very efficient for coronal preparation especially in lower molars, but their inadequate use may result in weakening dentinal walls. Lower fracture resistance of endodontically treated teeth is proportional to dentine deficit [22].

The introduction of NiTi rotary endodontic instruments have improved pre-defined tapered preparation, especially in the apical third. This group of highly flexible instruments enables quality and safe instrumentation from the coronal to the apical part due to their design and taper (2-12\%). Moreover, these NiTi spreaders enable safe manipulation in the root canal during rotary preparation and the preservation of the initial root canal shape. Problems that may happen even to experienced clinicians during canal preparation, such as artificial canals, may be avoided with these instruments. Explaining the differences between stainless steel and NiTi instruments, Carvalho et al. claimed that the latter have a tendency to follow the original canal centre [23]. The risk with stainless steel instruments lies in the possibility to prepare morphological steps and ledges in the apical segment. Therefore, the use of flexible hand instruments is recommended in this segment [23].

Rotary instrumentation is equally efficient in the preparation of coronal, apical and middle segments whilst hand instruments are generally used to prepare the apical thirds of curved canals of the buccal-mesial roots of lower first molars. The balanced force technique is recommended since it removes less dentine tissue. Significantly more dentine tissue is removed from the apical segment using NiTi rotary instruments and this may affect the prognosis of the endodontic treatment [24].

\section{CONCLUSION}

The present results indicated that dentine production is greatest in the population between 25 and 50 and, therefore and this is the population where least complications during canal instrumentation are to be expected. The least volume of dentine in the apical part of the root canal is found in the youngest population (under 25). In this population, erroneous overextensions and weakening dentinal walls may occur during canal preparation.

\section{REFERENCES}

1. Filipović V, Gvozdenović-Sedlecki S, Karadžov O, Kezele D, Kolak Ž, Kuburović D, et al. Endodoncija. Beograd: Dečije novine; 1989.

2. Ten Cate AR. Oral Histology - Development, Structure, and Function. $6^{\text {th }}$ ed. St. Louis: Mosby; 2002.

3. Mjor IA, Heyeraas KJ. Pulp-dentin biology in restorative dentistry. Part I: Normal structure and physiology. Quintessence Int. 2001; 32:427-46.

4. Sedlecki-Gvozdenović S. Pulpa zuba čoveka u odnosu na doba života, stanje tvrdih zubnih tkiva i parodoncijuma [doktorska disertacija]. Beograd: Univerzitet u Beogradu; 1976. 
5. Morse DR, Esposito JV, Schoor RS, Williams FL, Furst ML. A review of aging of dental component and a retrospective radiographic study of aging of the dental pulp and dentin in normal teeth. Quintessence Int. 1991; 22:711-20.

6. Stein TJ, Corcoran JF. Anatomy of the root apex and its histologic changes with age. Oral Surg Oral Med Oral Pathol. 1990; 69:238-42.

7. Wheeler S, Ash M. Dental antomy, phisiology and occlussion. 8th ed. Nelson: Elsevier Science; 2003.

8. Azaz B, Michaeli Y, Nitzan D. Aging of tissue of the roots of non fuctional human teeth (impacted canines). Oral Surg Oral Med Oral Pathol. 1977; 43:527-8.

9. Gulabivala K, Aung TH, Alavi A, Ng YL. Root and canal morphology of Burmese mandibular molars. Int Endodont J. 2001; 34:359-70.

10. Gulabivala K, Opasanon A, Ng YL, Alavi A. Root and canal morphology of The mandibular molars. Int Endodont J. 2002; 35:56-60.

11. Tamse A, Littner MM, Kaffe J, Mascona D, Gavish A. Morphological and radiographic study of the apical foramen in distal roots of mandibular molar. Part I: The location of the apical foramen on various roots aspects. Intl Endodont J. 1988; 21:205-10.

12. Tamse A, Littner MM, Kaffe J, Mascona D, Gavish A. Morphological and radiogrphic study of the apical foramen in distal roots of mandibular molars. Part II: The distance between the foramen and the root. Int Endodont J. 2002; 35:56-66.

13. Dammaschk T, Witt M, Ott K, Schafer E. Scanning electron microscopic investigation of incidence, location, and size of accessory foramina in primary and permanent molars. Quintessence Int. 2004; 35:699-705.

14. Fava LR, Siqueira JF. Considerations in working length determination. Endodontic Practice. 2000; 3:22-32.

15. Blaskovic-Subat V, Maricic B, Sutalo J. Asymetry of the root canal foramen. Int Endodont J. 1992; 25:158-64.

16. Cunningam C), Senia ES. A three-dimensional study of canal curvatures in the mesial roots of mandibular molars. J Endodont. 1992; 18:294-300
17. Goel NK, Gill KS, Tanej JR. Study of root configuration in mandibular first permanent molar. J Indian Soc Pedod Prev Dent. 1991; 8:12-4.

18. Haddad GY, Nehme WB, Ounsi HF. Diagnosis, classiffication, and frequensy of C-shaped canals an mandibular second molars Lebanese population. J Endodont. 1999; 25:268-71.

19. Kartal N, Cimilli HK. The degrees and configurations of mesial canal curvatures of mandibular first molars. J Endodont. 1997; 23:358-62.

20. Mjor IA, Smith MR, Ferrari M, Mannocci F. The structure of dentine in the apical region of human teeth. Int Endodont J. 2001; 34:346-53.

21. Furri M, Tocchio C, Bonaccorso A, Tripi TR, Cantatore G. Apical canal confluency in mandibular molars. Endo 2007; 1:53-9.

22. Wu MK, van der Sluis LWM, Wesselink PR. The risk of furcal perforation in mandibular molars using Gates-Glidden drills with anticurvature pressure. Oral Surg Oral Med Oral Pathol Oral Radiol Endod 2005; 99:378-82.

23. Bonaccorso A, Tripi TR. II nichel-titanio in endodonzia. Bologna: Edizioni Martina; 2006.

24. Vertucci FJ. Root canal morphology and its relationship to endodontic procedures. Endodontic Topics 2005; 10:3-29.

\author{
Address for correspondence \\ Milica Jovanović-Medojević \\ Klinika za bolesti zuba \\ Stomatološki fakultet \\ Rankeova 4, 11000 Beograd \\ Srbija \\ Tel.: +381(0)112443366 \\ Email: amedojevic@sbb.co.rs
}




\title{
Debljina primarnog i sekundarnog dentina u predelu apeksnog otvora na mezijalnom i distalnom korenu prvog donjeg stalnog molara
}

\author{
Milica Jovanović-Medojević \\ Klinika za bolesti zuba, Stomatološki fakultet, Univerzitet u Beogradu, Beograd, Srbija
}

\begin{abstract}
KRATAK SADRŽAJ
Uvod Poznavanje kompleksnosti kanalskog sistema prvih donjih molara, posebno apeksnog dela korena zuba, značajno utiče na pravilnu realizaciju i uspeh endodontskog lečenja.

Cilj rada Cilj rada je bio da se kod zuba različitih starosnih kategorija odredi debljina primarnog i sekundarnog dentina oko glavnog otvora kanala na mezijalnom i distalnom korenu prvih donjih stalnih molara.

Materijal i metode rada Kao materijal u istraživanju korišćeno je 50 prvih donjih molara osoba oba pola ekstrahovanih zbog različitih indikacija. Svi zubi su, prema starosti, svrstani u tri kategorije: uzorci do 25 godina starosti (15 zuba), uzorci stari 26-50 godina (20 zuba) i uzorci stariji od 50 godina ( 15 zuba). Nakon formiranja pristupnog kaviteta, ulazi u kanale korena su levkasto prošireni i urađena je eksploracija kanala ručnim instrumentima tipa K10. Potom je pomoću dijamantskog diska odsečen vrh korena do mesta otvora kanala na korenu. Analiza debljine dentina oko glavnog otvora urađena je pomoću kompleksne konfiguracije nekoliko uređaja koji su međusobno bili softverski povezani. To su polarizacioni mikroskop (Leica DMLSP), digitalna kamera (Leica DC300) i skener.

Rezultati Najveća prosečna debljina primarnog dentina na mezijalnom korenu prvog donjeg molara uočena je u prvoj grupi $0,177 \mathrm{~mm}$; u trećoj je bila 0,145 mm, dok je najmanja prosečna debljina zabeležena u drugoj grupi $-0,141 \mathrm{~mm}$. Najveća prosečna debljina primarnog dentina na distalnom korenu zabeležena je u drugoj grupi - 0,175 mm; u prvoj je bila 0,138 mm, dok je najmanja prosečna debljina dentina uočena u trećoj grupi $-0,100 \mathrm{~mm}$. Najveća prosečna debljina sekundarnog dentina na mezijalnom korenu prvog donjeg molara ustanovljena je u drugoj grupi - 1,25 mm; u trećoj je bila 1,11 mm, dok je najmanja prosečna debljina zabeležena u prvoj grupi $-0,95 \mathrm{~mm}$. Najveća prosečna debljina sekundarnog dentina na distalnom korenu prvog donjeg molara uočena je u drugoj grupi $-1,26 \mathrm{~mm}$; $\mathrm{u}$ trećoj je bila $1,18 \mathrm{~mm}$, dok je najmanja zabeležena u prvoj grupi $-0,99 \mathrm{~mm}$.

Zaključak Rezultati su pokazali da je prosečna debljina primarnog dentina na mezijalnom i distalnom korenu bila približno jednaka. Prosečna debljina sekundarnog dentina bila je najveća na mezijalnom korenu zuba starih između 26 i 50 godina. Najveća prosečna debljina sekundarnog dentina uočena je na distalnom korenu takođe u ovoj grupi.
\end{abstract}

Ključne reči: donji prvi molar; kanal korena; dentin; dentalna anatomija; endodontsko lečenje

\section{UVOD}

Poznavanje morfologije korenskog kanalnog sistema zuba je preduslov uspešnog lečenja obolele pulpe. Pulpno-dentinski kompleks, kao i sva tkiva čoveka, prolazi kroz određene promene tokom procesa starenja. Jedna od značajnijih promena je smanjenje zapremine komore pulpe i kanala korena zuba usled stalnog procesa stvaranja dentina [1]. Kod starih zuba korenski kanal je često u vidu tankog proreza i ponekad može biti potpuno obliterisan. Takva kontinuirana restrikcija zapremine komore pulpe dovodi do smanjenja vaskularizacije pulpnog tkiva i često izaziva razne promene u metabolizmu i probleme u lečenju obolele pulpe zuba [2]. Ove promene su najčešće posledica starenja, kao i brojnih fizioloških i patoloških faktora. Fiziološke promene se odigravaju kao proces adaptacije na fiziološke nadražaje u funkciji vremena, a patološke nastaju kada određeni faktori prevazilaze fiziološke granice adaptacije [3].

Starenjem sekundarni dentin postaje nepravilne građe i postoji tendencija zatvaranja (opturacije) dentinskih tubula [4]. Najveće promene se odigravaju u intratubularnom dentinu, gde na kraju dolazi i do skleroze tubula, tj. formiranja transparentnog dentina. Formiranje atubularnog dentina počinje od apeksa korena i sa godinama se širi prema krunici, dovodeći do smanjenja propustljivosti dentina [2]. Ovo se često koristi za procenu starosti dentina, jer postoji statistički značajna zavisnost između smanjenja dentinskih tubula i godina [5].

Promene koje se sa starenjem odigravaju na tvrdim zubnim tkivima utiču i na izgled i funkciju zubne pulpe. Apeksna depozicija sekundarnog dentina i taloženje cementa sužavaju prvobitnu širinu apeksnog otvora, kroz koji prolaze krvni i limfni sudovi i nervna vlakna. Ovaj prolaz može biti kompromitovan sužavanjem otvora, tako da u dubokoj starosti može potpuno da suprimira vaskularizaciju, limfnu drenažu i inervaciju $[5,6]$.

Posle dvadesete godine broj ćelija pulpe se smanjuje, da bi u sedamdesetim godinama bio sveden na svega polovinu prvobitnog broja. Može se reći da fiziološke aktivnosti pulpe i parodoncijuma tokom života dovode do modeliranja i anatomije apeksne trećine korena, pa i samim tim i anatomije apeksnog konusa, što je od presudnog značaja za uspeh endodontskog lečenja $[7,8]$.

Savremene tendencije endodontske terapije podrazumevaju biološki pristup pri preparaciji i obradi korenskog kanala, prateći njegovu dužinu i prirodni (zatečeni) oblik. Najzahtevniji segment pri obradi kanala svakako je apeksna trećina, koja se obrađuje različitim endodontskim tehnikama (Step-back, Crown-down). Ovaj postupak olakšava obradu, irigaciju i medikaciju apeksnog dela. Sve komplikacije pri preparaciji apeksa, kao što su lomljenje instrumenta, slabljenje zida, prelom korena i slično, mogu se izbeći ukoliko endodontist poznaje oblik, zakrivljenja i volumensku dimenziju ovog segmenta. Osnovno načelo pri oblikovanju kanala podrazumeva preparaciju bez promene anatomskog oblika i sa što manjim uklanjanjem dentinske supstance upravo u apeksnom delu korena. S obzirom na to da su prvi donji molari ključ za održavanje normalnog okluzivnog odnosa, normalne funkcije žvakanja i uopšte 
održavanja normalne funkcije stomatognatnog sistema, njihovo očuvanje u ustima predstavlja najveći izazov za veliki broj stomatologa praktičara.

Cilj ovoga rada je bio da se kod zuba različitih starosnih kategorija odredi debljina primarnog i sekundarnog dentina oko glavnog otvora kanala na mezijalnom i distalnom korenu prvih donjih stalnih molara.

\section{MATERIJAL I METODE RADA}

Kao materijal u istraživanju korišćeno je 50 prvih mandibularnih molara osoba oba pola ekstrahovanih zbog različitih indikacija. Svi zubi su, prema starosti, svrstani u tri grupe: prvu grupu su činili uzorci do 25 godina starosti (15 zuba), drugu uzorci stari 26-50 godina (20 zuba), a treću uzorci stariji od 50 godina (15 zuba). Zubi su nakon ekstrakcije čuvani u četvoroprocentnom rastvoru formalina. Posle detaljnog debridmana krunice i korena od čvrstih i mekih tkiva, uzorci su čuvani u fiziološkom rastvoru do početka eksperimenta. Kod svih zuba urađena je preparacija odgovarajućeg pristupnog kaviteta turbinskim kolenjakom i fisurnim dijamantskim svrdlom. Ulazi u korenske kanale su levkasto prošireni mašinskim instrumentom (Pezzo \#2), a početna eksploracija koronarne i srednje trećine kanala korena izvedena je ručnim endodontskim instrumentima ISO10. Vrhovi korena su primenom dijamantskog diska (Disco Plan-TS) presecani u nivou otvora kanala na vrhu korena. Da bi se dobio preparat koji se može posmatrati na polarizacionom mikroskopu, drugi presek je napravljen milimetar koronarnije.

Istraživanje je izvedeno na Katedri za petrologiju Instituta za mineralogiju, kristalografiju, petrologiju i geohemiju Rudarskogeološkog fakulteta Univerziteta u Beogradu, a podrazumevalo je analizu apeksne trećine mezijalnog i distalnog korena prvog donjeg molara 50 ekstrahovanih zuba svrstanih u tri pomenute starosne kategorije. Korišćena je kompleksna konfiguracija nekoliko uređaja, koji su međusobno bili softverski povezani (Slika 1). To su polarizacioni mikroskop za propuštenu svetlost (Leica DMLSP), na kojem se nalazi digitalna kamera (Leica DC300). Posebnim programom (Leica IM50) omogućena je tzv. živa slika koja se posmatra na monitoru. Sastavni deo opreme je i skener koji ima mogućnost skeniranja preparata $\mathrm{u}$ odbijenoj svetlosti uz upotrebu specijalnih folija.

Mikroskopska proučavanja obuhvatila su sledeće postupke:

1. izradu petrografskih preparata;

2. posmatranje i opis uzoraka proučavanjem na polarizacionom mikroskopu u uslovima propuštene svetlosti;

3. izradu i obradu snimaka (mikrofotografija) ispitivanih uzoraka zuba;

4. skeniranje preparata u odbijenoj svetlosti; i

5. analizu dobijenih snimaka.

\section{Izrada petrografskih preparata}

Petrografski preparat je komadić tanko isečenog uzorka stene (debljine oko 0,02 mm) koji se zalepi između predmetnog i pokrovnog stakla. Ovako tanak uzorak je providan i može da propušta svetlost, čime se omogućava analiza polarizacionim mikroskopom. Analogno ovome, napravljeni su preparati gde su kao uzorci korišćene apeksne trećine korena zuba (uz neophodno menjanje procedure i prilagođavanje uzorcima) s najmanjom debljinom preparata od $0,025 \mathrm{~mm}$ do $0,030 \mathrm{~mm}$.

Izrada ovih preparata obuhvatila je sledeće postupke:

- brušenje uzoraka (apeksne trećine korena zuba) primenom dijamantskih diskova (Disco Plan-TS) od vrha korena do pojave otvora kanalića;

- poliranje uzorka;

- lepljenje uzorka za predmetno staklo dvokomponentnim lepkom (Cerapox), čiji je indeks prelamanja svetlosti 1,537;

- fino poliranje površine celog preparata abrazivima 600 1200' (meša);

- nanošenje spreja za preparate kao zaštitnog sloja.

\section{Proučavanja u polarizacionom mikroskopu}

Polarizacioni mikroskop omogućava posmatranje objekata u polarizovanoj svetlosti. Kao izvor svetlosti koristi običnu belu svetlost, koja se propuštanjem kroz polarizator linearno polariše, i tek tako dobijeni zrak dolazi do uzorka koji se posmatra. Svaki uzorak (mineral, staklo, koren zuba i sl.), propuštajući ovakav zrak, dovodi do njegove modifikacije shodno svojim specifičnim optičkim svojstvima. Tako promenjen zrak se zatim propušta kroz objektiv do tzv. analizatora. Ova pločica može biti isključena i tada se objekat posmatra u uslovima paralelnih nikola (N//) ili, pak, može biti uključena, kada se predmet posmatra u uslovima ukrštenih nikola $(\mathrm{Nx})$. Posle analizatora zraci prolaze kroz okular do oka posmatrača, koji ih dešifruje kao optičke osobenosti posmatranog uzorka i određuje cilj onoga što proučava.

Uzorci apeksne trećine korena posmatrani su u uslovima ortoskopskih ispitivanja s ukrštenim nikolima, budući da su pod tim okolnostima najviše dolazile do izražaja morfološke odlike tkiva, tj. zuba koje je trebalo analizirati.

\section{Izrada i obrada snimaka}

Mikrofotografije su rađene u uslovima ukrštenih nikola primenom objektiva s uvećanjem od pet puta i okulara 10. Naknadne obrade snimaka vršene su pomoću grafičkih programa Photoshop 7 i Corel Photopaint 9.0.

Često je uvećanje od pet puta bilo suvišno, tako da ispitivani objekat nije mogao da stane u vidno polje kamere. Stoga je nedostatak objektiva manjeg uvećanja nadomešten izradom paket-fotografija (od dva do šest snimaka) koje se jednim delom preklapaju. Spajanjem ovih fotografija u jednu celinu pomoću programa Canon Photostitcher 2.2 dobijana je jedna reprezentativna fotografija uzorka.

\section{Skeniranje preparata}

Dodatna ispitivanja vršena su i analizom fotografija koje su dobijene skeniranjem preparata u odbijenoj svetlosti. Tokom skeniranja kao poseban dodatak korišćene su specijalne folije kojima se dobijaju efekti ukrštenih nikola u polarizacionom mikroskopu, te je bilo moguće jasno razlikovati različita tkiva, njihova morfološka svojstva, promene i drugo. 


\section{Analiza snimaka}

Analiza snimaka preseka apeksnih otvora kanala korena zuba dobijenih na polarizacionom mikroskopu izvedena je $u$ grafičkom programu Photoshop 7. Nakon merenja stvarnih dimenzija svakog preparata pomoću nonijusa (Calipretto-S, 1122-1000, Renfert, Germany), te vrednosti su unošene u Image Size pri analizi datog preparata. Na osnovu proporcije koju Photoshop 7 sam uspostavlja moguće je dobiti prave mere željenih struktura na preparatu. Na ovaj način obavljena su merenja veličine kanala, tj. otvora, najveća debljina primarnog i sekundarnog dentina i najveća debljina primarnog i sekundarnog cementa mezijalnih i distalnih korenova prvih mandibularnih molara.

\section{REZULTATI}

Najveća prosečna debljina primarnog dentina na mezijalnom korenu prvog donjeg molara uočena je u prvoj grupi - 0,177 $\mathrm{mm}$ ); u trećoj je bila $0,145 \mathrm{~mm}$, dok je najmanja prosečna debljina primarnog dentina zabeležena u drugoj starosnoj grupi - 0,141 mm (Tabela 1, Slika 2).

Najveća prosečna debljina primarnog dentina na distalnom korenu prvog donjeg molara zabeležena je u drugoj grupi - 0,175 mm; u prvoj je bila $0,138 \mathrm{~mm}$, dok je najmanja prosečna debljina primarnog dentina otkrivena u trećoj grupi $0,100 \mathrm{~mm}$ (Tabela 1$)$.

Najveća prosečna debljina sekundarnog dentina na mezijalnom korenu prvog donjeg molara ustanovljena je u drugoj grupi - 1,25 mm; u trećoj je bila $1,11 \mathrm{~mm}$, dok je najmanja prosečna debljina sekundarnog dentina zabeležena u prvoj grupi - 0,95 mm (Tabela 2).

Najveća prosečna debljina sekundarnog dentina na distalnom korenu prvog donjeg molara uočena je u drugoj grupi $1,26 \mathrm{~mm}$; u trećoj je bila 1,18 mm, dok je u prvoj grupi bila najmanja - 0,99 mm (Tabela 3, Slika 3).

\section{DISKUSIJA}

S obzirom na to da su prvi donji molari ključ za održavanje normalnog okluzivnog odnosa, normalne funkcije žvakanja i uopšte održavanja normalne funkcije stomatognatnog sistema, njihovo očuvanje u ustima predstavlja najveći izazov za veliki broj stomatologa praktičara. Relativna jednostavnost $\mathrm{i}$ uniformnost spoljašnje površine mezijalnog i distalnog korena najčešće maskiraju njihovu unutrašnju komplikovanost i kompleksnost $[9,10]$.

Dvokoreni mandibularni molar najčešće ima tri kanala. Dva se nalaze u mezijalnom korenu, a jedan u distalnom. Najveći broj ispitivanja potvrđuje da mezijalni koren uvek ima dva kanala (meziobukalni i meziolingvalni), ali s različitom Vertučijevom (Vertucci) konfiguracijom. Analize morfoloških varijacija ovih zuba su pokazale da je tip III zastupljen u $60 \%$, a tip II u $40 \%$ slučajeva [7].

Distalni koren najčešće ima jedan kanal s konfiguracijom tipa II po Vertučiju [7]. Mezijalni koren, zbog svoje dvokanalne konfiguracije, pa čak i distalni, kod kojeg postoji mogućnost pojave drugog kanala, zanimljivi su za endodontiste zbog mogućih istmusa. Istmus je uzan, trakast spoj između dva korenska kanala koji sadrži pulpno tkivo i u literaturi se može naći pod različitim nazivima: koridor, lateralni spoj, transverzalna anastomoza. Neophodno je istaći da svaki koren koji ima dva kanala ima i veliku prevalenciju za istmuse [11]. Veler (Weller) i saradnici su 1995. godine pokazali da se istmus najčešće pojavljuje na 3-5 mm od apeksa. Istmus inače predstavlja veliki izazov tokom endodontskog lečenja, jer može funkcionisati kao bakterijski rezervoar, pa neadekvatna obrada i opturacija kanalskog sistema, odnosno njegovo zanemarivanje, mogu dovesti do neuspešnog lečenja $[12,13]$.

Druga zanimljiva istraživanja ukazuju na to da se najveće devijacije apeksnog foramena dešavaju na korenovima, gde se na zubu formiraju mastikatorni centri (meziobukalni koren gornjeg molara i distalni koren donjeg molara) [14]. Ovi koreni trpe najveći mastikatorni pritisak, tako da nagomilavanje cementna predstavlja proces adaptacije na funkcionalne i fiziološke stresove [15].

Na osnovu dobijenih rezultata o prosečnoj maksimalnoj debljini sekundarnog dentina na mezijalnom i distalnom korenu donjeg prvog molara potvrđuje se teorija da je 50. godina starosti prelomna u produktivnom potencijalu dentina [3]. Najveće vrednosti debljine dentina u apeksnom delu korena su uočene u drugoj starosnoj grupi, dok su najstarijoj manje. Treba je naglasiti da postoji uzročno-posledična veza između najveće $\mathrm{i}$ najmanje debljine sekundarnog dentina. Na osnovu jednačine linearne regresije se, ukoliko je poznata jedna vrednost, druga može vrlo lako odrediti. U dostupnoj literaturi nije pronađen parametar kojim bi se mogli upoređivati rezultati o debljini primarnog i sekundarnog dentina u predelu anatomskog otvora, mezijalnog i distalnog korena prvog donjeg molara. Zato su rezultati dobijeni u ovom istraživanju primenom polarizacionog mikroskopa originalni, retki i, naravno, veoma značajni za postupak endodontskog lečenja $[15,17,18,19]$.

Eventualni nedostaci ovih metričkih analiza mogu se objasniti korišćenim uzorkom, odnosno činjenicom da nije bio zabeležen razlog ekstrakcije zuba (ortodontski razlozi, infekcija periapeksa). Potvrđeno je da debljina primarnog dentina na mezijalnom i distalnom korenu prvog donjeg molara može da bude posledica i različitih načina ekstrakcije zuba korišćenih kao uzorak [20].

Uočavanje složenosti korenskog kanalnog sistema, a posebno kod komplikovanih oblika donjih prvih molara, i postavljanje tačne dijagnoze su važan parametar za svakog stomatologa pre početka endodontskog lečenja. Drugim rečima, dobra dijagnoza udružena s preciznim anatomskim znanjem mora biti povezana s perfektnom biomehaničkom obradom. Svi ovi faktori vode do uspešnog trodimenzionalnog punjenja korenskog kanalnog sistema [15].

Problem obrade kanala u apeksnom regionu uskih kanala sa zakrivljenjima (kakvi su najčešće meziobukalni i meziolingvalni kanali prvih donjih molara) takođe može biti vezan za mnoge poteškoće. Tokom obrade kanala sa zakrivljenjima korišćeni instrument agresivnije pritiska stranu suprotnu od krivine i rezultat toga je stvaranje još veće krivine, što uzrokuje teškoće pri irigaciji, širenju i opturaciji kanala [21]. Tokom endodontskog lečenja, osim tačne lokalizacije apeksne granice, neophodno je odrediti i dobru volumensku ekstenziju biomehaničke preparacije apeksne trećine kanala korena, kako bi se izbegli problemi i onemogućila pojava uzdužnih fraktura 
zuba tokom instrumentacije i opturacije kanala korena. Ukoliko dođe do predimenzioniranja apeksne preparacije, postoji mogućnost da zid korena oslabi i primenom tehnika kompakcije gutaperke frakturira. Time se, naravno, utiče i na potpuni neuspeh endodontskog lečenja, ali i na eventualnu promenu plana protetičke rehabilitacije ukoliko se takav zub mora ekstrahovati [20].

Trend konusne obrade kanala je prihvaćen tokom poslednje dve decenije. Široka konusna obrada koronarnog dela korenskog kanala je presudna u endodontskoj terapiji komplikovanih molarnih sistema, jer omogućava bolji pristup apeksnom delu, kontrolu instrumentacije, bolju irigaciju i efikasnije uklanjanje razmaznog sloja. Mašinski proširivači (Gates Glidden i Peeso) se smatraju veoma efikasnim u koronarnoj obradi, posebno donjih molara, ali njihova neadekvatna primena može dovesti do drastičnog smanjenja debljine zida dentina. Smanjena otpornost endodontski lečenih zuba ka frakturama proporcionalno se povećava sa većim nedostatkom dentina [22].

Napredak u predefinisanoj konusnoj obradi kanala, a posebno apeksne trećine, postignut je uvođenjem NiTi rotirajućih endodontskih instrumenata. Ova grupa visokofleksibilnih instrumenata svojim dizajnom i konusnošću (2-12\%) dozvoljava kvalitetnu i sigurnu instrumentaciju kanala, počev od kruničnog do apeksnog dela korena. Štaviše, ovi NiTi proširivači omogućavaju sigurnu manipulaciju u kanalu primenom mašinske rotacije i čuvanje inicijalnog oblika kanala. Problemi koji se mogu dogoditi i najiskusnijem praktičaru tokom obrade kanala, kao i lateralna perforacija, na ovaj način se mogu izbeći. Karvaljo (Carvalho) i saradnici, objašnjavajući razliku između čeličnih i NiTi instrumenata, tvrde da NiTi instrumenti imaju tendenciju da prate centar kanala [23]. Rizik kod primene čeličnih endodontskih instrumenata je u dobijanju kanala morfološkim stepenicama u apeksnom segmentu. Zbog toga se u ovom segmentu preporučuje korišćenje ručnih fleksibilnih instrumenata [23].

Mašinskom instrumentacijom se ostvaruje podjednako efikasno koronarno, apeksno i središnje proširenje korena, dok se ručnim instrumentima obično obrađuje vrh korena zuba. Zbog toga su ručni fleksibilni instrumenti bezbedniji za obradu apeksne trećine zakrivljenih kanala, zakrivljenih bukomezijalnih korenova prvih donjih molara, primenom tehnike balansirane sile, jer uklanjaju manje dentinskog tkiva. Sloj uklonjenog dentina iz korenskog kanala je značajno veći primenom NiTi rotirajućih instrumenata, što može uticati i na dalju prognozu endodontski lečenog zuba [24].

\section{ZAKLJUČAK}

Rezultati ovog istraživanja su pokazali da je najveće stvaranje dentina kod ljudi starih između 25 i 50 godina. To je populacija kod koje se mogu očekivati najmanje komplikacije pri instrumentaciji kanala. Najmanji volumen dentinskog sloja u apeksnom delu kanala je kod osoba starih do 25 godina, pa su kod njih moguće greške u vidu preekstenzije i slabljenja zidova kanala korena tokom izvođenja endodontskog postupka. 